\title{
Kemampuan Pemecahan Masalah Dinamika Partikel pada Mahasiswa Calon Guru Fisika Berdasarkan Taxonomy of Introductory Physics Problems (TIPP)
}

\author{
Taskirah Tunnisah, Syamsu, dan I Komang Werdhiana \\ taskirahfisika@gmail.com \\ Program Studi Pendidikan Fisika FKIP Universitas Tadulako \\ Jl. Soekarno Hatta Km. 9 Kampus Bumi Tadulako Tondo Palu - Sulawesi Tengah
}

Penelitian ini bertujuan untuk mengetahui, menganalisis serta mendeskripsikan kemampuan pemecahan masalah dinamika partikel pada mahasiswa calon guru fisika berdasarkan Taxonomy of Introductory Physics Problems (TIPP). Jenis penelitian ini merupakan penelitian deskriptif-kualitatif. Penelitian ini dilakukan di Program Studi Pendidikan Fisika, Fakultas Keguruan dan Ilmu Pendidikan Universitas Tadulako. Subyek penelitian adalah mahasiswa angkatan 2014 yang terdiri dari 26 orang. Responden penelitian ditentukan berdasarkan hasil tes seleksi responden. Data diperoleh melalui lembar jawaban mahasiswa, rekaman Thinking-Aloud (TA) dan wawancara. Tes Seleksi Responden (TSR) terdiri atas 20 butir soal Pilihan Ganda yang digunakan untuk menentukan responden sebanyak 6 orang. Tes pemecahan masalah terdiri atas 5 butir soal esai yang dikerjakan oleh masing-masing responden. Hasil penelitian menunjukkan bahwa kemampuan pemecahan masalah mahasiswa calon guru fisika berada dalam kategori kurang, dengan nilai rata-rata sebesar 50,00. Salah satu faktor yang mempengaruhi adalah kebanyakan mahasiswa hanya mengetahui persamaan dan bunyi hukum Newton tanpa memahami konsep dari Hukum Newton itu sendiri. Selain itu, minat mahasiswa dalam mengerjakan masalah-masalah yang berkaitan dengan aplikasi dari Hukum-Hukum Newton juga sangat rendah yang menyebabkan tingkat analisis soal yang kurang dan berrpengaruh terhadap kemampuan pemecahan masalah mahasiswa calon guru fisika.

Kata Kunci : Analisis, kemampuan pemecahan masalah fisika, taxonomy of introductory physics problems

\section{PENDAhULUAN}

Pembelajaran sains pada calon guru yang menekankan pada kemampuan pemecahan masalah dapat mengembangkan keterampilan proses sains dan meningkatkan kualitas diri calon guru sehingga dapat mencapai kesuksesan di dunia kerjanya nanti ${ }^{[1]}$.

Pemecahan masalah/soal merupakan aspek penerapan konsep-konsep fisika yang diperoleh melalui proses belajar. Kebutuhan pemecahan masalah muncul ketika seseorang ingin mencapai tujuan yang diinginkan. Soal fisika pada umumnya merupakan tugas yang meminta seseorang melakukan serentetan tindakan yang membawanya dari kondisi awal menuju ke kondisi akhir yang diinginkan. Langkah-langkah tindakan yang teridentifikasi dengan baik akan menghasilkan solusi atau penyelesaian soal ${ }^{[2]}$.

Kemampuan mahasiswa calon guru dalam memecahkan masalah salah satunya dipengaruhi oleh kemampuan kognitif/aktivitas mental (otak) dalam memahami konteks soal yang diberikan. Pemahaman yang baik terhadap konsep-konsep dan prinsip-prinsip fisika, menyebabkan keterampilan dalam memecahkan masalah-masalah fisika akan semakin baik. Saat menghadapi sebuah masalah mahasiswa dituntut untuk membangun hubungan antara pengetahuan baru dengan pengetahuan yang telah ada sebelumnya dalam menemukan sebuah penyelesaian.

Teoderescu et. al, menciptakan sebuah taksonomi baru, khusus untuk pengklasifikasian masalah-masalah fisika berdasarkan proses kognitif mahasiswa. Taksonomi tersebut dikenal dengan sebutan Taxonomy of Introductory Physics Problem (TIPP). Taksonomi ini mengacu pada taksonomi yang diciptakan oleh Marzano dan Kendall atau dikenal dengan The New Taxonomy of Educational Objectives (NTEO). TIPP terdiri atas beberapa level, yaitu: Level 1: Retrieval (Pencarian keterangan), Level 2: Comphrehension (Pemahaman), Level 3: Analysis (Analisis), dan Level 4: Knowledge Utilization (Pemanfaatan pengetahuan) $)^{[3]}$. Dalam penelitian ini, proses kognitif mahasiswa dapat dilihat dari kemampuan mahasiswa 
dalam menyelesaikan tes kemampuan pemecahan masalah fisika.

\section{METODE PENELITIAN}

Penelitian ini menggunakan pendekatan deskriptif-kualitatif yang datanya berupa faktafakta yang ada. Subyek dalam penelitian ini adalah mahasiswa calon guru fisika kelas C angkatan 2014 yang berjumlah 26 orang. Responden dalam penelitian ini sebanyak 6 (enam) orang yang dipilih berdasarkan skor hasil Tes Seleksi Responden (TSR). Soal TSR berjumlah 20 butir soal diberikan kepada subyek penelitian yaitu 26 orang mahasiswa calon guru fisika. Data dari hasil pemberian TSR, kemudian dihitung skor rata-rata dan standar deviasi. Skor yang diperoleh tersebut, dikelompokkan berdasarkan kategori tinggi, sedang dan rendah seperti yang ditunjukkan pada Tabel 1.

Tabel 1.Skor perolehan TSR

\begin{tabular}{|c|c|c|c|c|}
\hline No & Inisial Mahasiswa & Skor & Nilai & Kategori \\
\hline 1. & S-01 & 16 & 80 & Tinggi \\
2. & S -02 & 14 & 70 & Tinggi \\
3. & S -03 & 12 & 60 & Tinggi \\
4. & $\mathrm{~S}-04$ & 11 & 55 & Sedang \\
5. & $\mathrm{~S}-05$ & 11 & 55 & Sedang \\
6. & $\mathrm{~S}-06$ & 11 & 55 & Sedang \\
7. & $\mathrm{~S}-07$ & 10 & 50 & Sedang \\
8. & $\mathrm{~S}-08$ & 10 & 50 & Sedang \\
9. & $\mathrm{~S}-09$ & 10 & 50 & Sedang \\
10. & $\mathrm{~S}-10$ & 9 & 45 & Sedang \\
11. & $\mathrm{~S}-11$ & 9 & 45 & Sedang \\
12. & $\mathrm{~S}-12$ & 9 & 45 & Sedang \\
13. & $\mathrm{~S}-13$ & 8 & 40 & Sedang \\
14. & $\mathrm{~S}-14$ & 8 & 40 & Sedang \\
15. & $\mathrm{~S}-15$ & 8 & 40 & Sedang \\
16. & $\mathrm{~S}-16$ & 8 & 40 & Sedang \\
17. & $\mathrm{~S}-17$ & 8 & 40 & Sedang \\
18. & $\mathrm{~S}-18$ & 7 & 35 & Sedang \\
19. & $\mathrm{~S}-19$ & 7 & 35 & Sedang \\
20. & $\mathrm{~S}-20$ & 7 & 35 & Sedang \\
21. & $\mathrm{~S}-21$ & 7 & 35 & Sedang \\
22. & $\mathrm{~S}-22$ & 6 & 30 & Rendah \\
23. & $\mathrm{~S}-23$ & 6 & 30 & Rendah \\
24. & $\mathrm{~S}-24$ & 6 & 30 & Rendah \\
25. & $\mathrm{~S}-25$ & 5 & 25 & Rendah \\
26. & $\mathrm{~S}-26$ & 5 & 25 & Rendah \\
\hline & $\overline{\mathrm{X}}$ & 8,77 & 43,85 & Sedang \\
\hline
\end{tabular}

Selanjutnya untuk 6 (enam) orang responden akan diberikan tes TA dan wawancara yang dipilih berdasarkan kategori berikut:

* Kategori tinggi, diperoleh dengan rumus: Nilai $>\bar{x}+$ SD

* Kategori sedang, diperoleh dengan rumus: $\overline{\mathrm{x}}-\mathrm{SD} \leq$ Nilai $\leq \overline{\mathrm{x}}+\mathrm{SD}$

* Kategori rendah, diperoleh dengan rumus: Nilai $<\overline{\mathrm{x}}-\mathrm{SD}$
Berdasarkan hasil perolehan data, skor ratarata yang diperoleh adalah 43,85 dan nilai standar deviasi adalah 13,03. Adapun dari skor rata-rata dan standar deviasi tersebut, maka responden yang terpilih untuk diberikan tes TA dan wawancara berdasarkan kategori disajikan pada Tabel 2.

Masing-masing responden diberikan tes TA sebanyak 5 butir soal esai yang memuat tentang materi dinamika partikel, yaitu khususnya pada materi hukum-hukum Newton. Tes TA yang diberikan bertujuan untuk mengetahui proses kognitif dan domain pengetahuan yang digunakan oleh responden saat memecahkan masalah. Proses pemecahan masalah yang digunakan dianalisis dengan menggunakan rubrik penilaian yang telah divalidasi oleh validasi ahli (expert judgment).

Tabel 2 Kode dan Kategori Responden

\begin{tabular}{|c|c|c|}
\hline No & Inisial Responden & Kategori \\
\hline 1 & S-01 & Tinggi \\
2 & S-02 & Tinggi \\
3 & S-07 & Sedang \\
4 & S-14 & Sedang \\
5 & S-25 & Rendah \\
6 & S-26 & Rendah \\
\hline
\end{tabular}

Topik utama penelitian ini menitikberatkan pada gambaran kemampuan pemecahan masalah mahasiswa calon guru fisika dalam menyelesaikan masalah-masalah fisika berdasarkan TIPP. Dalam hal kemampuan pemecahan masalah, peneliti melihat kesesuaian jawaban subjek penelitian dengan skor jawaban yang terdapat pada rubrik penilaian. Pada penelitian ini, kategori soal terbagi atas tiga tingkatan/level yaitu penarikan pengetahuan, analisis dan pemanfaatan pengetahuan. Dari ketiga level tersebut kemudian dibagi atas lima butir soal TA yang telah diklasifikasikan berdasarkan TIPP.

Pengidentifikasian proses kognitif mahasiswa bermuara pada proses berpikir mahasiswa calon guru dalam mengolah informasi yang diberikan dalam soal, sedangkan untuk domain pengetahuan bermuara pada cara yang digunakan mahasiswa dalam menyelesaikan masalah yang diberikan. Penentuan peneliti terhadap keenam responden yang diberikan tes TA bermaksud untuk mengungkapkan proses kognitif apa saja yang dilakukan mahasiswa calon guru dalam pemecahan masalah fisika.

Teoderescu ${ }^{[3]}$ mengungkapkan bahwa terdapat hubungan antara proses kognitif, domain pengetahuan dan masalah-masalah fisika. Sehingga pada aspek pemecahan 
masalah fisika yang dilakukan mahasiswa calon guru dilihat pada langkah-langkah yang digunakan mahasiswa dalam menjawab soal. Oleh sebab itu, dilihat pengaruhnya antara mahasiswa yang mempunyai proses kognitif yang banyak dibandingkan dengan mahasiswa yang mempunyai proses kognitif yang sedikit dalam menyelesaikan masalah fisika.

\section{HASIL DAN PEMBAHASAN}

Hasil analisis kemampuan memecahkan masalah responden per butir soal dapat dilihat pada Tabel 3.

Tabel 3. Hasil Analisis Kemampuan Pemecahan Masalah Responden Per Butir Soal

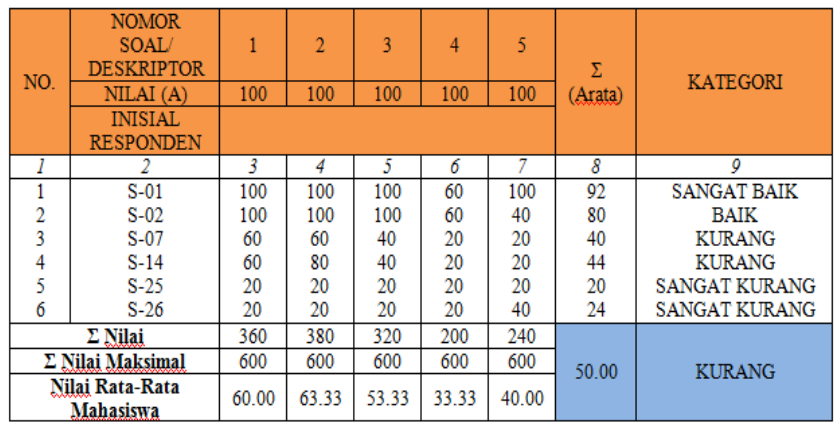

Berdasarkan hasil yang ditunjukkan pada tabel di atas, secara umum nilai rata-rata kemampuan pemecahan masalah dinamika partikel oleh keenam responden adalah sebesar 50,00 . Nilai rata-rata yang diperoleh tersebut mengindikasikan bahwa kemampuan pemecahan masalah mahasiswa calon guru fisika berada pada kategori kurang dengan nilai yang seharusnya dicapai adalah 71 dengan kategori baik. Sedangkan untuk nilai rata-rata kemampuan pemecahan masalah diperoleh pada butir soal pertama yaitu 60,00 berada pada rentang kategori cukup, butir soal kedua yaitu 63,33 berada pada kategori cukup, butir soal ketiga yaitu 53,33 dengan kategori kurang, butir soal keempat 33,33 dengan kategori sangat kurang, dan butir soal kelima 40,00 dengan kategori kurang.

Dari kelima nomor soal yang ada, untuk keenam responden mempunyai tingkat kemampuan pemecahan masalah yang berbeda-beda. Hal ini dapat dilihat pada nilai rata-rata yang diperoleh masing-masing responden yang ditunjukkan pada tabel 3.2. Responden kategori tinggi (S-01 dan S-02) mempunyai nilai rata-rata 92 dan 80 , dengan kategori kemampuan pemecahan masalah sangat baik dan baik. Responden dengan kategori sedang (S-07 dan S-14) mempunyai nilai rata-rata 40 dan 44 dengan kategori kemampuan pemecahan masalah kurang. Serta responden dengan kategori rendah (S-25 dan S-26) mempunyai nilai rata-rata 20 dan 24 dengan kategori kemampuan pemecahan masalah sangat kurang. Hasil tersebut menggambarkan bahwa pengkategorian responden berdasarkan hasil TSR berbanding lurus dengan nilai hasil kemampuan pemecahan masalah yang diperoleh responden saat diberikan tes TA.

Berdasarkan hal tersebut dapat dilihat bahwa pengetahuan awal responden mengenai materi hukum-hukum Newton menentukan hasil tes kemampuan pemecahan masalah yang diberikan. Hal ini sejalan dengan pendapat Teoderescu ${ }^{[3]}$ mahasiswa yang memecahkan masalah berkali-kali mempunyai proses kognitif dan pengetahuan yang berbeda-beda dengan mahasiswa yang baru pertama kali melihat masalah. Berdasarkan analisis hasil pekerjaan keenam responden dalam memecahkan masalah fisika, diperoleh hasil untuk masingmasing deskripsi per butir soal yang disajikan dalam uraian berikut ini.

\subsection{Deskripsi Kemampuan Pemecahan Masalah Level 1}

Masalah-masalah fisika yang disajikkan pada level ini terdapat pada butir soal nomor 2 bagian a dan $b$. Pada butir soal kedua nilai ratarata yang diperoleh yaitu 63,33 atau dengan kata lain nilai yang diperoleh berada dalam kategori cukup. Masalah fisika yang diberikan pada mahasiswa calon guru berkaitan dengan proses kognitif mengenali atau mengidentifikasi tentang gaya aksi-reaksi atau lebih dikenal dengan Hukum III Newton. Sedangkan untuk domain pengetahuan mahasiswa calon guru diharapkan dapat melibatkan pengetahuan informasi dan prosedur mental terkait karakteristik dari bunyi Hukum III Newton.

Berdasarkan hasil analis jawaban tes TA, terlihat bahwa dari keenam responden, untuk responden kategori tinggi menggunakan kedua domain pengetahuannya, sedangkan untuk empat orang responden lainnya hanya melibatkan domain pengetahuan informasi dan tidak menggunakan prosedur mentalnya. Hal ini salah satunya terlihat pada responden S-25. Berikut kutipan jawaban responden S-25. 


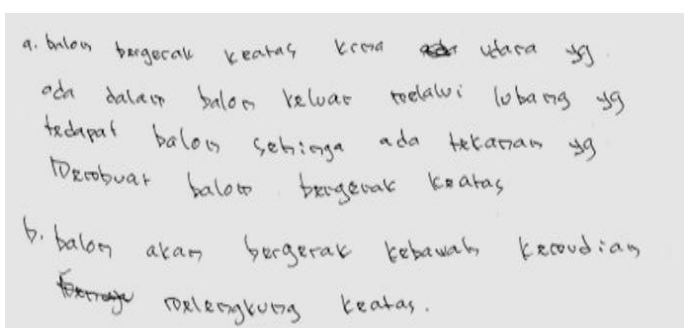

Gambar 1 Kutipan Jawaban S-25 pada Soal Nomor 2 Bagian a dan b

Saat menyelesaikan permasalahan ini, S-25 mempunyai proses kognitif mengidentifikasi yang sangat minim. Hal ini terlihat pada saat memecahkan masalah S-25 tidak mengaitkan sedikitpun soal dengan Hukum III Newton, responden hanya membayangkan dan menuliskan bahwa udara yang ada di dalam balon akan keluar dan balon akan terbang ke atas.

Berikut potongan transkip S-25 pada soal nomor 2 bagian a dan $b$.

a. $\{---\}$ Balon bergerak ke atas karena ada udara yang ada dalam balon keluar melalui lubang yang terdapat pada balon sehingga balon $\{--\}$ sehingga ada tekanan yang membuat balon yang bergerak ke atas.

b. Bagian b, balon akan bergerak ke bawah kemudian menuju ke atas eh melengkung ke atas $\{---\}$

Penjelasan responden S-25 pada kutipan TA di atas menggambarkan bahwa kemampuan memecahkan masalah pada proses kognitif level 1 yaitu penarikan pengetahuan deskriptor mengidentifikasi masih kurang. Hal ini karena S-25 sudah tidak mengingat gaya aksi reaksi yang dinyatakan dalam Hukum III Newton. Dalam kegiatan wawancara, responden telah memahami apa yang ditanyakan namun tidak tahu mengenai konsepnya, sehingga S-25 hanya memberikan jawaban dengan pengetahuan informasi yang berkaitan dengan pernyataan yang diberikan oleh soal. Hal ini dikarenakan responden jarang menemui soal yang berkaitan dengan konsep Hukum III Newton, sehingga penggunaan konsep aksi reaksi tentang Hukum III Newton belum dapat diidentifikasi dengan benar.

Walsh et al (2007) berpendapat bahwa dalam memecahkan masalah, individu-individu perlu keberhasilan mentransfer pengetahuan mereka dari konteks pertama kali dipelajari ke konteks masalah khusus (dimana dalam fisika sering menerapkan pengetahuan dari suatu konteks abstrak, konteks yang diidealkan ke konteks yang lebih konkrit) ${ }^{[4]}$.

\subsection{Deskripsi Kemampuan Pemecahan Masalah Level 3}

Masalah fisika pada level ini disajikan pada butir soal nomor 2 bagian c, dimana responden diminta untuk menyimpulkan suatu kejadian mengenai hukum III Newton. Berdasarkan kutipan jawaban, kelima responden dapat menyimpulkan bahwa pada balon terjadi gaya aksi reaksi yang memenuhi pernyataan tentang hukum III Newton. Terdapat satu orang responden yaitu S-25 yang belum dapat menyimpulkan tentang gaya aksi reaksi yang terjadi pada balon tersebut. Hal ini dikarenakan bahwa responden tidak dapat menganalisis dengan baik pernyataan yang diberikan pada soal bagian a dan b yang menyangkut gaya aksi reaksi. Dari hasil wawancara responden mengetahui tentang persamaan Hukum III Newton namun lupa dengan bunyi Hukum III Newton. Hal tersebut menggambarkan bahwa responden menggunakan pengetahuan deklaratifnya yaitu mengetahui bahwa Hukum III Newton itu adalah $F_{a k s i}$ sama dengan negatif

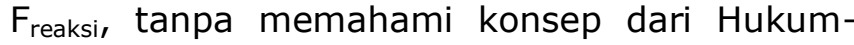
Hukum Newton itu sendiri. Sehingga responden tidak dapat menyelesaikan soal analisis (menyimpulkan) dengan benar.

Adapun hasil yang diperoleh pada kemampuan pemecahan masalah level 3 yaitu terdapat $33,33 \%$ responden yang mendapat skor $5,16,67 \%$ untuk skor $4,16,67 \%$ untuk skor 3 dan 33,33\% untuk skor 1 . Sehingga dapat dikatakan bahwa mahasiswa calon guru mempunyai kemampuan pemecahan masalah yang cukup dalam proses mengidentifikasi masalah Hukum III Newton.

\subsection{Deskripsi Kemampuan Pemecahan Masalah Level 4}

Masalah-masalah fisika yang disajikan pada level ini terdapat pada butir soal nomor 1, 3, 4 dan 5. Pada level ini, mahasiswa diberikan masalah-masalah fisika yang berkaitan dengan penggunaan pengetahuannya mengenai penerapan Hukum I Newton dan Hukum II Newton. Berikut disajikan deskripsi untuk masing-masing jawaban responden per butir soal.

\section{Deskripsi Jawaban Responden untuk Butir Soal Nomor 1}

Pada butir soal pertama, nilai rata-rata yang diperoleh adalah 60,00 berada dalam kategori cukup. Dari keenam responden, terdapat dua orang yang mampu menjawab dengan benar dan mencapai skor 5, sedangkan untuk keempat responden lainnya mempunyai 
jawaban yang bervariasi. Pada butir soal nomor 1 , mahasiswa calon guru diberikan masalah terkait dengan penerapan/contoh dari konsep Hukum I Newton. Kemampuan pemecahan masalah mahasiswa calon guru dalam menyelesaikan permasalahan pada deskriptor ini memiliki pengetahuan yang berbeda-beda, hal ini terlihat pada responden dengan kategori tinggi, sedang dan rendah.

Dari keenam responden, terdapat dua responden dengan kategori tinggi menjawab dengan dua domain pengetahuan sekaligus yaitu informasi dan prosedur mental. Sedangkan untuk keem

pat responden lainnya hanya menggunakan pengetahuan informasi atau prosedur mentalnya saja. Hal ini terlihat pada Responden S-07, hanya melibatkan pengetahuan prosedur mental saat memecahkan masalah. Saat menyelesaikan masalah S-07 hanya menuliskan persamaan dari Hukum I Newton tanpa menjelaskan hubungan antara keadaan uang koin yang telah memenuhi Hukum I Newton dengan konsep Hukum I Newton itu sendiri. Ini berarti pengetahuan responden dalam menerapkan pengetahuannya mengenai bunyi Hukum I Newton sangat kurang. Kutipan jawaban S-07 ditunjukkan pada Gambar 2.

Dalam kegiatan wawancara responden mengaku bahwa lupa dengan bunyi Hukum I Newton sehingga hanya menuliskan persamaannnya. Hal tersebut sangat mendukung bahwa S-07 mempunyai latar belakang pengetahuan fisika mengenai Hukum I Newton yang sangat kurang.

\section{Jawab: Hang koin bersedout tidak akan tarkambur barena telab manamuin, hukam I nawiton yalth $\bar{i} F=0$ \\ Gambar 2 Kutipan Jawaban S-07 pada Soal Nomor 1.}

Berbeda halnya dengan ketiga responden yang hanya melibatkan pengetahuan informasinya saja. Salah satu responden yang melibatkan pengetahuan informasinya adalah S-26. Pada kutipan transkip TA di atas terlihat bahwa S-26 mengaitkan informasi yang diberikan pada soal dengan pengetahuan informasi yang dimilikinya mengenai Hukum I Newton. Tetapi dalam menuliskan jawaban S26 terlebih dahulu membaca secara berulangulang maksud soal pada kalimat "setelah ditarik dengan satu hentakan lurus, apakah yang terjadi pada tumpukan uang koin tersebut". Setelah itu, S-26 menuliskan jawabannya bahwa uang koin akan terjatuh atau berantakan, dan mencoba mengingat kembali bunyi dari Hukum I newton. Berikut kutipan jawaban responden S-26 pada gambar 3.

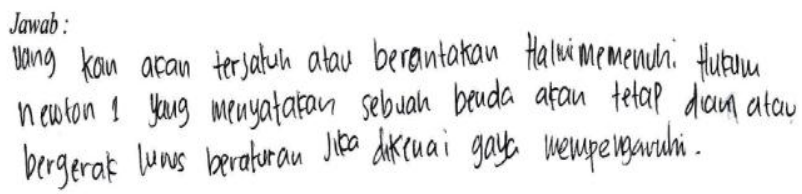

Gambar 3.Kutipan Jawaban S-26 pada Soal Nomor 1.

Kemampuan pemecahan masalah S-26 terhadap masalah fisika yang berhubungan dengan Hukum I Newton terlihat hanya sebatas pada benda yang bergerak dengan kecepatan konstan, tanpa memahami bahwa sebuah benda akan tetap mempertahankan keadaannya meski ada gaya luar yang mengenai benda tersebut. Sehingga dari deskripsi soal yang ada maka keadaan koin akan cenderung tetap diam di atas meja meskipun ada gaya tarik yang mempengaruhi keadaannya atau dengan kata lain sifat kemalasan benda untuk mengubah kedudukannya (inersia).

Saat menyelesaikan masalah, S-26 hanya fokus kepada keadaan uang koin setelah kertas ditarik dengan cepat, namun tidak mengambil informasi terkait keadaan koin tersebut yang memenuhi hukum I Newton. Sehingga dapat disimpulkan bahwa S-26 mempunyai pengetahuan informasi yang kurang serta belum dapat menyelesaikan masalah yang berhubungan dengan kasus penerapan dari bunyi Hukum I Newton.

Berbeda halnya dengan S-01, responden dengan kategori tinggi ini menyelesaikan soal nomor 1 dengan dua proses kognitif yaitu penggunaan informasi dan prosedur mental. S01 pertama-tama memahami pernyataan yang diberikan oleh soal. Kemudian mencermati maksud dari soal yang mengarah ke jawaban yang diinginkan. Analisa informasi penyelesaian ditunjukkan oleh potongan transkip TA berikut ini.

$\{---\}$ Hukum I Newton itu $\Sigma F=0$. Dimana Hukum I Newton disebut juga dengan Hukum kelembaman. Nah, pada Hukum kelembaman ini setiap benda akan mempertahankan kedudukannya. Jadi ketika uang koin tersebut memenuhi Hukum I Newton dan ketika ujung kertas ditarik maka yang terjadi adalah tumpukan uang koin tersebut akan tetap pada kedudukannya. Ya, karena pada dasarnya benda yang diam akan terus diam dan benda yang bergerak akan terus bergerak dengan kecepatan tetap ketika tidak ada gaya luar yang mempengaruhinya. $\{\ldots\}$ jadi di sini gayanya itu 
dianggap nol atau tidak ada gaya yang mempengaruhi dia. Jadi ketika ujung kertasnya ditarik jadi uang koin tetap pada kedudukannya \{--\}.

Berdasarkan kutipan jawaban dan TA responden di atas, terlihat bahwa S-01 terlebih dahulu memahami maksud dari pernyataan soal kemudian menerapkannya pada kasus uang koin tersebut. Proses kognitif pada deskriptor ini mengarah ke proses penerapan pengetahuan tentang bunyi Hukum I Newton yang diberikan dalam soal. Dalam menyelesaikan permasalahan ini, S-01 mempunyai domain pengetahuan (informasi) yang lebih baik dibandingkan dengan S-26 tentang penerapan dari bunyi Hukum I Newton, sehingga dapat menjawab dengan benar soal nomor 1 .

Hasil yang diperoleh pada butir soal nomor 1 yaitu terdapat $33,33 \%$ responden yang mendapat skor 5, 33,33\% untuk skor 3, dan $33,33 \%$ untuk skor 1 . Sehingga dapat dikatakan bahwa mahasiswa calon guru mempunyai kemampuan pemecahan masalah yang cukup dalam menerapkan kembali informasi yang telah diberikan dalam proses pembelajaran fisika.

\section{Deskripsi jawaban responden untuk butir soal nomor 3}

Nilai rata-rata responden yang diperoleh pada deskriptor ini yaitu sebesar 53,33 berada dalam kategori kurang. Masalah fisika yang diberikan dalam deskriptor ini berkaitan dengan Hukum II Newton yang melibatkan domain pengetahuan informasi dan prosedur mental. Ross dalam Teoderescu ${ }^{[3]}$ mengemukakan bahwa sasaran pengetahuan yang digunakan dalam memecahkan masalah fisika ada dua yaitu pengetahuan deklaratif (informasi) dan pengetahuan prosedural (prosedur mental).

Dalam menuliskan jawaban, sebagian besar responden masih belum bisa menentukan rumus yang digunakan sesuai dengan pernyataan yang diberikan dalam soal. Hal ini terdapat pada keempat responden yang hanya mencapai skor 1 dalam menerapkan konsep Hukum II Newton. Berikut kutipan jawaban salah satu responden (S-14) pada butir soal nomor 3 .

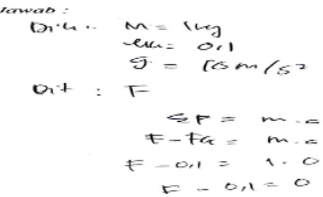

Gambar 4 Kutipan Jawaban S-14 pada Soal Nomor 3.
Saat menyelesaikan permasalahan di atas, S-14 terlebih dahulu membaca soal kemudian menuliskan variabel-variabel yang diketahui. Dari sini dapat dilihat bahwa, S-14 menggunakan pengetahuan informasi untuk dapat memilih variabel yang akan digunakan dalam menyelesaikan permasalahan tersebut. Sedangkan untuk prosedur mental terlihat bahwa S-14 dapat merencanakan strategi yang akan digunakan dalam hal ini responden menuliskan persamaan yang ingin dipakai dalam menghitung besar gaya tarik $\mathrm{F}$ sehingga balok dapat bergerak lurus beraturan. Dalam kegiatan wawancara, responden juga mengatakan bahwa ia lupa untuk menghitung besar gaya normal dan gaya gesek kinetik dalam menyelesaikan permasalahan di atas. Berikut kutipan wawancaranya.

\begin{tabular}{|c|c|}
\hline Peneliti & $\begin{array}{l}\text { Dari soal yang ada apa saja besaran } \\
\text { yang ingin dicari nilainya sehingga } \\
\text { dapat menghitung besar gaya tarik } \\
\text { F? }\end{array}$ \\
\hline$S-14$ & $\begin{array}{l}\text { Dalam soal diketahui bahwa balok } \\
\text { terletak di atas permukaan bidang } \\
\text { datar sehingga dicari dulu gaya } \\
\text { normalnya. }\end{array}$ \\
\hline Peneliti & : Terus? \\
\hline S-14 & $\begin{array}{c}\text { : Kemudian, dimasukkan nilainya ke } \\
\text { dalam persamaan Hukum II }\end{array}$ \\
\hline & $\begin{array}{l}\text { Newton, yaitu sigma } F \text { sama } \\
\text { dengan m.a. }\end{array}$ \\
\hline Peneliti & $\begin{array}{l}\text { : Bagaimana dengan nilai gaya gesek } \\
\text { kinetiknya? }\end{array}$ \\
\hline-14 & $\begin{array}{l}\text { Saya lupa kak...makannya saya } \\
\text { langsung gunakan nilai koefisien } \\
\text { gesek kinetik karena yang diketahui } \\
\text { di soal itu. }\end{array}$ \\
\hline
\end{tabular}

Kutipan wawancara di atas terlihat bahwa S14 kurang menggunakan pengetahuan prosedur mentalnya. Langkah-langkah penyelesaian yang digunakan hanya berupa menuliskan persamaan akhir tanpa memahami besaran yang harus dicari terlebih dahulu sebelum menghitung besar gaya tarik $F$. Proses ini terlihat berbeda dengan responden kategori tinggi. S-02 menyelesaikan soal dengan menggunakan dua domain pengetahuan sekaligus yaitu informasi dan prosedur mental. Langkah pertama S-02 adalah memahami informasi yang ada di dalam soal dengan membaca soal sebanyak 2 kali pengulangan. Kemudian menentukan besar gaya normal, setelah itu responden mencari nilai gaya gesek kinetik, serta menentukan nilai akhir yaitu besar gaya tarik F. Berikut kutipan jawaban S02 pada Gambar 5. 


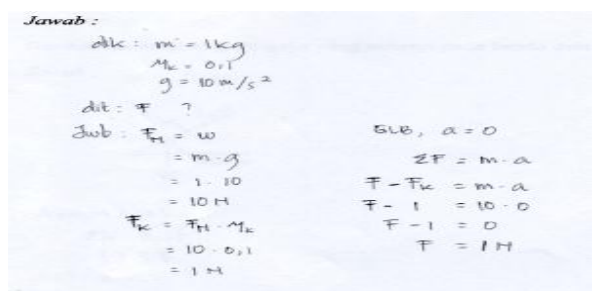

Gambar 5 Kutipan Jawaban S-02 pada Soal Nomor 3.

Berdasarkan Gambar 5, dapat dilihat bahwa responden dengan kategori tinggi mempunyai langkah-langkah penyelesaian (pengetahuan informasi dan prosedur mental) yang lebih banyak dibandingkan dengan responden dengan kategori rendah. Hal ini dikarenakan responden dengan kategori tinggi lebih sering menemukan masalah sehingga mempunyai proses kognitif yang berbeda dengan responden kategori sedang dan rendah yang jarang menemui/menyelesaikan masalah-masalah fisika dan berhubungan dengan proses pemecahan masalah yang dituliskan ketika diberikan soal.

Hal tersebut sejalan dengan pendapat Haper (2006), menyoroti tentang perbedaan perilaku pembelajar yang terampil (expert) dengan pembelajar yang kurang terampil (novice) dalam memecahkan masalah fisika. Expert memandang pemecahan masalah sebagai suatu proses, sementara novice berpikir bahwa pemecahan masalah merupakan tugas mengingat kembali (recall task) ${ }^{[5]}$.

Adapun kemampuan pemecahan masalah pada deskriptor butir soal nomor 3 yaitu memecahkan masalah, terdapat 33,33\% responden yang memperoleh skor 5, 33,33\% responden yang memperoleh skor 2, dan $33,33 \%$ responden yang memperoleh skor 1 . Dari hasil tersebut dapat dikatakan bahwa sebagian besar mahasiswa kurang mampu menyelesaikan permasalahan fisika yang berhubungan dengan penerapan hukum II Newton.

\section{Deskripsi jawaban responden untuk butir soal nomor 4}

Pada butir soal nomor 4 , nilai rata-rata yang diperoleh keenam responden adalah sebesar 33,33 dengan rentang kategori kurang sekali. Pada level ini proses kognitif siswa diarahkan untuk mengkonstruksi sebuah gambar secara tepat dengan menggunakan informasi dan prosesur mental dalam menyelesaikan permasalahan soal nomor 4. Masalah fisika yang diberikan berkaitan dengan menganalis gaya-gaya yang bekerja pada benda dalam komponen sumbu $X$ dan $Y$ serta menghitung besar percepatan benda yang berada pada bidang miring licin. Berdasarkan jawaban yang dituliskan, sebagian besar responden masih kesulitan dalam menggambarkan analisis gayagaya yang bekerja, serta tidak dapat menentukan persamaan yang digunakan. Berikut kutipan jawaban responden oleh S-26:

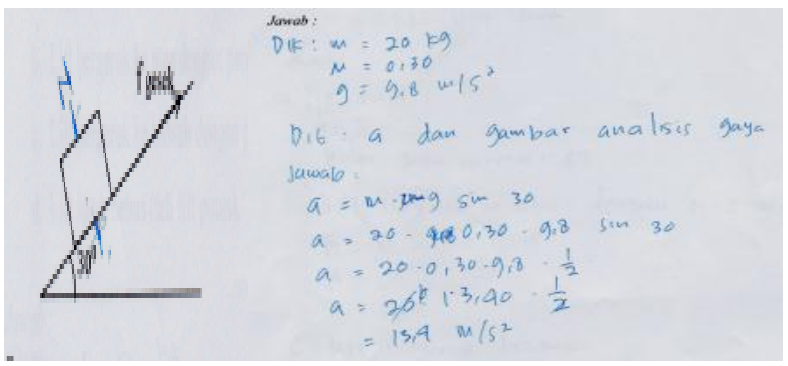

Gambar 6 Kutipan Jawaban S-26 pada Soal Nomor 4.

Berdasarkan Gambar 6, terlihat bahwa S-26 mempunyai proses kognitif yang sangat kurang. Dari ke empat responden, yaitu responden kategori sedang dan rendah mempunyai domain pengetahuan yang sama saat menyelesaikan permasalahan soal nomor 4 . Hal ini dikarenakan mahasiswa tidak terbiasa mengerjakan soal-soal yang meminta untuk merepresentasikan gaya-gaya yang bekerja pada sebuah benda yang menggeser ke bawah saat berada di atas bidang miring.

Berdasarkan kutipan TA, dapat dilihat bahwa keempat responden pada kategori sedang dan rendah tidak dapat menyelesaikan permasalahan fisika. Keempat responden hanya mengidentifikasi variabel yang diketahui dalam soal dan mengaku sudah tidak tahu lagi rumus yang digunakan. Keempat responden mengaku bahwa jarang menemui soal yang mempunyai perintah menggambarkan skema gaya-gaya yang bekerja. Padahal dengan menggambarkan gaya-gaya yang bekerja pada komponen sumbu $x$ dan y dapat memudahkan responden dalam menemukan persamaan untuk menyelesaikan permasalahan di atas.

Berbeda dengan responden pada kategori tinggi, kedua responden ini terlebih dahulu menggambarkan skema gaya-gaya yang bekerja sehingga memudahkan dalam menganalisis maksud soal dan dapat menemukan persamaan yang digunakan. Meskipun jawaban S-01 dan S-02 mempunyai hasil akhir yang salah tetapi kedua responden dapat memahami maksud soal yang diberikan. Kedua responden mengalami kesalahan pada perhitungan akhir sehingga skor yang diperoleh 
adalah 3. Hal tersebut sejalan dengan pendapat Haper ${ }^{[5]}$ mengemukakan bahwa expert menggunakan representasi non-matematik seperti grafik, bagan, dan diagram secara luas sementara novice cenderung kurang menggunakan representasi non matematik

Kemampuan pemecahan masalah pada deskriptor ini yaitu sebesar 33,33\% responden yang memperoleh skor 3, serta 66,67\% responden yang memperoleh skor 1 . Sehingga dapat dikatakan bahwa sebagian besar mahasiswa kurang memiliki kemampuan menerapkan pengetahuan dalam menyelesaikan permasalahan fisika yang menghubungkan proses kognitif dan domain pengetahuan yang dimiliki.

\section{Deskripsi jawaban responden untuk butir soal nomor 5}

Kemampuan pemecahan masalah keenam responden pada butir soal nomor 5 diperoleh nilai rata-rata sebesar 40,00 dengan kategori kurang sekali. Pada deskriptor ini responden diberikan masalah fisika yang berkaitan dengan penerapan bunyi Hukum II Newton. Penyelesaian permasalahan pada butir soal deskriptor ini, sebagaian besar responden kurang mengaitkan hubungan antara poin a dengan b, dan c. Sehingga mahasiswa masih kesulitan dalam menentukan besar gaya normal yang dialami oleh sesorang ketika berada di dalam lift. Hal ini terlihat pada ketiga responden yang hanya mempunyai skor 1 pada butir soal kelima. Sedangkan untuk responden dengan kategori tinggi dapat menyelsaikan permasalahan dengan proses kognitif yang berbeda. Berikut kutipan jawaban oleh S-25 (responden dengan kategori rendah) pada butir soal kelima:

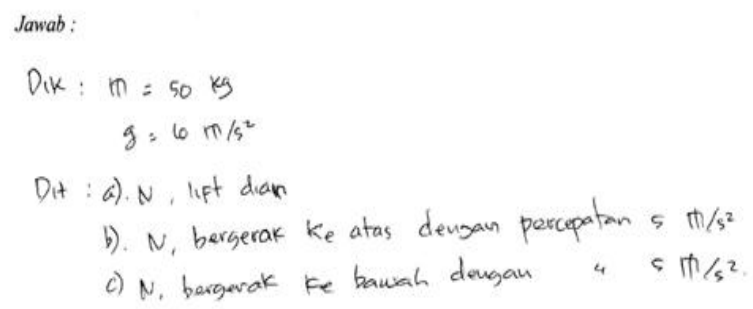

Gambar 7 Kutipan Jawaban S-25 pada Soal Nomor 5.

S-25 menyelesaikan permasalahan di atas dengan proses kognitif yaitu hanya memetakan variabel-variabel yang diketahui dalam soal, kemudian responden mengaku bahwa tidak mengetahui lagi rumus yang digunakan Dalam menuliskan jawaban, responden tidak dapat menggambarkan representasi gaya-gaya yang bekerja dalam lift sehingga tidak dapat menentukan besar gaya normal serta keterkaitan anatar soal bagian a, b, dan c.

Secara umum, responden tidak dapat menyelsaikan pemasalahan ini. Hal ini terlihat pada kategori tinggi, sedang dan rendah. Responden dengan kategori tinggi, S-02 hanya menjawab soal bagian a, sedangkan untuk bagian b dan $c$ responden mengaku tidak mengetahui rumus yang digunakan. Sedangkan untuk responden kategori sedang dan rendah sama sekali tidak bisa menyelesaikan butir soal nomor 5 . Ketiga responden hanya mengidentifikasi variabel yang diketahui dalam soal dan mengaku bahwa soal yang diberikan sulit.

Kemampuan mahasiswa calon guru pada deskriptor memecahkan masalah adalah $16,67 \%$ responden memperoleh skor 5, $33,33 \%$ responden memperoleh skor 2 , dan $50,00 \%$ responden yang memperoleh skor 1 .

Hasil analisis data berdasarkan tes TA kemampuan pemecahan masalah serta wawancara yang telah dilakukan dengan keenam responden menunjukkan bahwa responden yang berada pada kategori tinggi mempunyai proses kognitif yang lebih banyak dibandingkan dengan responden kategori sedang dan rendah dalam menyelesaikan tes TA. Larkin menyimpulkan bahwa seorang yang menjadi expert setelah melalui latihan pengalaman memecahkan soal-soal yang sama memperoleh kesimpulan yang sama memecahkan 5 soal mekanika menggunakan Thinking Aloud dianalisis ke dalam alur penyelesaian dan menyatakan bahwa: untuk bekerja pada masalah tersebut, problem solver harus mengkonversi rangkaian kata-kata, dengan itu ia menampilkan ke dalam beberapa representasi mental internal yang dapat dimanipulasi dalam upaya memecahkan masalah tersebut ${ }^{[6]}$.

Oleh karena itu proses mahasiswa calon guru di atas berkaitan dengan latar belakang pengetahuan yang dimiliki oleh masing-masing responden pada materi hukum-hukum Newton. Sehingga dapat disimpulkan bahwa mahasiswa mempunyai kemampuan pemecahan masalah yang masih kurang pada proses kognitif dan domain pengetahuan. Hal ini dikarenakan mahasiswa calon guru jarang menemui masalah-masalah fisika yang telah diklasifikasikan berdasarkan proses kognitif dan domain pengetahuan yang dilibatkan saat memecahkan masalah fisika. Kebanyakan mahasiswa langsung memasukkan persamaan 
tanpa menganalisis terlebih dahulu pokok permasalahan yang ditanyakan. Kemudian mahasiswa lebih sering diberikan soal-soal yang memuat nilai-nilai dan langsung dapat dikonversikan ke dalam rumus matematis. Keadaan seperti inilah yang menyebabkan rendahnya kemampuan mahasiswa calon guru dalam memecahkan masalah fisika.

\section{KESIMPULAN DAN SARAN}

\section{KESIMPULAN}

Berdasarkan hasil penelitian yang telah dilakukan diperoleh kesimpulan bahwa

1. Kemampuan pemecahan masalah mahasiswa calon guru fisika pada materi dinamika partikel berada pada kategori kurang, yaitu 50,00 . Salah satu faktor yang mempengaruhi adalah kebanyakan mahasiswa hanya mengetahui persamaan dan bunyi hukum Newton tanpa memahami konsep dari Hukum Newton itu sendiri.

2. Perbedaan proses kognitif dan domain pengetahuan pada kategori mahasiswa calon guru disebabkan karena mahasiswa yang mempunyai proses kognitif yang banyak lebih sering menjumpai masalah-masalah fisika dibandingkan dengan mahasiswa dengan proses kognitif yang sedikit. Hal ini tentu saja berhubungan dengan pengetahuan yang dimiliki oleh mahasiswa calon guru saat memecahkan masalah fisika.

\section{SARAN}

Berdasarkan kesimpulan di atas, maka peneliti menyarankan :

1. Membiasakan mahasiswa untuk dapat menganalisis soal sebelum melakukan pemecahan masalah agar dapat memahami permasalahan inti pada soal dan dapat menyelesaikan permasalahan fisika dengan tepat.

2. Penelitian sejenis dapat dilakukan lagi untuk melihat hasil yang lebih baik dengan materi dan lokasi penelitian yang berbeda. Perbedaan materi dan lokasi mungkin saja berpengaruh pada kemampuan pemecahan masalah mahasiswa dalam memecahkan masalah fisika berdasarkan TIPP.

\section{Ucapan Terimakasih}

Akhir kata penulis menyampaikan ucapan terima kasih yang sebesar-besarnya kepada Bapak Drs. Syamsu, M. Si, Dr. I Komang Werdhiana, M. Si, Dr. Jusman Mansyur, M. Si dan Dr. Darsikin, M. Si atas diskusi dan masukkannya.

\section{DAFTAR PUSTAKA}

[1] Dogru, Mustafa. (2008). The Application of Problem Solving Method on Science Teacher Trainees on the Solution of the Enviromental Poblems. [Online] Tersedia:http://www.ijese.com/V3_N1_Dogru.pdf. [20 Februari 2015]

[2] Mundilarto. (2003). Kemampuan Mahasiswa MenggunakanPendekatan Analitis Kuantitatif dalam Pemecahan Soal Fisika. Jurnal Pendidikan Matematika dan Sains edisi 3 tahun VIII.

[3] Teoderescu, E. R, et al. (2013). New Approach to Analyzing Physics Problems A taxonomy of Introductory Physics Problems. Phys. Rev. ST Phys. Educ. Res. 9, 010103 (2).

[4] Walsh, L. N., et al. (2007). Phenomenographyc Study of Students Problem Solving Approaches in Physics. Phy. Rev. Spec. Topic-PER, 3, 020108 (2007).

[5] Haper, K. A. (2006). Student Problem Solving Behavior. The Physics Teacher 44, 250-251.

[6] Larkin, J. H. (1981). Understanding, Problem Representation and Skill in Physics. Thinking and Learning Skills, 2. 